\title{
THE FRANCHISOR/FRANCHISEE RELATIONSHIP: HOW CAN THIS RELATIONSHIP BE STRENGTHENED FROM THE FRANCHISEES' PERSPECTIVE?
}

\author{
Mimi Rickard, University of West Georgia, USA
}

\section{INTRODUCTION}

Franchising plays a major role in the U.S. economy by providing growth and jobs. The International Franchise Association reported in 2009, the franchising sector was accountable for 9.5 million jobs and provided nearly $\$ 845$ billion of economic output to the U.S. economy. Furthermore, for every new franchise business an estimated 20.6 either direct or indirect jobs are created and an additional \$2.2 million output is achieved (Chabowski, Hult, and Mena 2011). The International Franchise Association also reported that there has been a 15 percent increase of franchising establishments in a 9 year period (2001 2009) from 767,483 to 883,292 . Given these financial indicators, franchising has a major impact on the U.S. economy.

According to Blut, Backhaus, Heussler, Woisetschlager, Evanschitzky, and Ahlert (2011), a strong relationship between the franchisor and the franchisee can directly impact system success. However, this relationship is more complex than traditional business relationships because it is both a business relationship as well as a legally binding relationship (Bernstein 2004). Therefore, a closer examination is warranted (White 2010). Despite these relationships being more complex than traditional business, the academic literature primarily focuses on the franchisor-franchisee relationship from a single viewpoint. Specifically, the literature primarily examines the system from the franchisor perspective and not the franchisee perspective (Combs, Ketchen, and Hoover 2004; Grunhagen and Mittelstaedt 2000; Saraogi 2009). For notable examples see Croonen 2010; Davies, Walfried, Manolis, Prince, and Winsor 2009; Dickey 2003; Grunhagen and Dorsch 2003; Grunhagen and Mittelstaedt 2005; and Weaven and Frazer 2003. While understanding the relationship from the franchisor perspective is important, the franchisee can view the relationship differently than the franchisor (e.g., McIntyre, Gilbert, and Hite 2002).

Hence, a better understanding of the franchise system will aid in the economy by providing positive growth and jobs. Grunhagen, DiPietro, Stassen, and Frazer (2008) conclude that "strengthening and protecting franchisees" interest in an effort to take care of unit owners is usually in the franchisors' best interest". Therefore, a need to explore which marketing activities are best suited for strengthening the franchisor/franchisee relationship and promote franchise profits exists (Doherty and Alexander 2006; Hunt and Nevin 1974). To advance our understanding of the franchisor-franchisee relationship, the purpose of this study is to examine which services provided by the franchisor to the franchisee are perceived by the franchisee as supportive. For a franchisee, the quality of support they receive from the franchisor has to meet or exceed their expectations and the economic and psychosocial expectations of the working relationship need to be met (Davies et. al 2009).

\section{METHODOLOGY}

To accomplish the purpose of this study, the support literature will be examined. Building on the support literature, this study will examine support provided by the franchisor as opposed to focusing on support provided within an organization as the traditional support literature does. This will allow for the research to address context specific (franchisor-franchisee) aspect of support. Specifically, the research question becomes: What aspects of the franchisor-franchisee relationship aid in increasing a franchisees' perception of franchise support? By understanding which aspects of the franchisor-franchisee relationship aid in increase franchisee's perceptions of franchise support; a franchisor will be able to emphasize those factors and strengthen the relationship.

This study will examine the antecedents of franchisees' perceived franchise support. Specific antecedents examined will include advertising, brand value/recognition, and training services provided by the franchisor. In order to examine this relationship, primary data will be used via survey. Panel data has been chosen to insure complete surveys.

\section{IMPLICATIONS FOR THEORY AND PRACTICE}

Previous research has indicated the need to examine this relationship (White 2010). This is not a traditional business relationship and is more complex because of the legally binding relationship (Bernstein 2004). Therefore, furthering the understanding as to which marketing activities are best suited for strengthening the franchisor/franchisee relationship exist (Doherty and Alexander 2006; Hunt and Nevin 1974). Clearly examining the antecedents leading to perceived franchise support will provide not only franchisors but also the academic community a better understanding of franchise support.

References available on request. 